\title{
Skladenjske posebnosti slovenščine v razmerjih glagol - vezljivost - stavčni vzorec
}

\author{
Andreja Ž ELe \\ Inštitut za slovenski jezik Frana Ramovša, ZRC SAZU, Novi trg 2, \\ SI-1000Ljubljana, andrejaz@zrc-sazu.si
}

\section{SCN IV/1 [2011], 48-68}

Prispevek opozarja na nekatere skladenjske posebnosti v slovenščini, ki so odraz razmerij med vezljivostnimi zmožnostmi določenih glagolov in možnimi oz. razpoložljivimi stavčnimi vzorci v slovenščini. S tem v zvezi je opozorjeno na specifične lastnosti določenih udeležencev, na njihove udeleženske vloge, ki se na izrazni ravni kažejo kot razmerja med vezljivimi določili in obveznimi dopolnili.

The paper presents some of the syntactical peculiarities of Slovenian that are reflected in the relation between valence capabilities of certain verbs and sentence patterns that are possible in the Slovenian language. In connection with this we also discuss specific characteristics of certain participants and their participant roles that on the expressive level are reflected in relations between adverbial valency and obligatory complements.

Ključne besede: vezljivost, stavčni vzorec, sestavljeni udeleženec, obvezna dopolnila

Key words: valency, sentence pattern, complex participant, obligatory complements

\section{Posebnosti v glagolski in povedkovi vezljivosti}

1.1 Glagoli s pomenjem, ki omogoča, da je v osebku vršilec dejanja ali prizadeto $\mathrm{z}$ dejanjem $\mathrm{v}$ enako- ali (vsaj) podobnosporočilnih povedih. $V$ teh primerih je še bolj pomenljivo prikazano soodvisno razmerje med glagolsko vezljivostjo in stavkotvornimi zmožnostmi v okviru stavčnih povedi.

Tu bodo upoštevani samo glagoli, katerih pomenje se giblje v vzročno-posledičnem razmerju, ki z izhodiščno tvorno prehodnostjo (vsaj) nakazuje ostanke potencialne ergativnosti: 
ajati (Ženske so ajale ('pestovale') otroke > Otroci so ajali ('spali')), bivati (Ti ljudje bivajo ('živijo') umetnost > Umetnost biva ('obstaja') pri teh ljudeh), Dimnik buha ('meče') $\operatorname{dim}>$ Dim buha ('bruha'), Bušknil ('sunil') ga je ven > Bušknil ('hitro odšel') je ven, Buta ('udarja') z vrati: Vrata butajo ('udarjajo'), Kap(lj)a ('daje po kapljicah') zdravilo : Zdravilo kap(lj)a ('pada po kapljicah'), Veter kroži ('obrača') dim : Dim kroži ('se obrača / zavija'), Mati lije ('izloča') solze : Solze lijejo ('se izločajo'), Loputnila ('udarila') je z vrati: Vrata so loputnila ('udarila'), Veter niha ('ziba') vrv: Vrv niha ('se ziba'), Vojne obubožajo ('osiromašijo') ljudi : Ljudje obubožajo ('postanejo revni'), Tone piha ('izloča') toplo sapo: Topla sapa piha ('se izloča'), Tone pljuska ('razliva') mleko : Mleko pljuska ('se razliva'), Otroci polegajo ('tlačijo') travo : Trava polega ('upada'), Prenočevali ('dajali prenočišče') so ga: Prenočeval ('preživljal noči') je pri njih, Prezimijo ('ohranijo čez zimo') zelenjavo > Zelenjava prezimi ('se ohrani čez zimo'), Promovirali ('razglasili') so ga > Promoviral je ('pridobil je doktorski naziv'), Namerno so ga stradali ('postili') > Namerno je stradal ('se je postil'), Starajo ('povzročijo, da zori') sir : Sir stara ('zori'), Strmoglavili ('vrgli') so stari režim > Stari režim je strmoglavil ('je padel'), Gospodinja vre ('intenzivno kuha') juho > Juha vre ('peneče narašča'), Mati vzhaja ('povzročiti, da narašča') testo > Testo vzhaja ('se dviga'), V odprtino zadela ('tesno vstavi') smolo $>$ Smola zadela ('tesno zamaši') odprtino, Stacionirali ('namestili') so čete ob meji > Čete stacionirajo (so nameščene) ob meji, Zavibriral ('zatresel') je kitarsko struno > Kitarska struna je zavibrirala ('se je zatresla'), Zorijo ('starajo') sir > Sir zori ('se stara').

Glagoli, ki lahko v osebku vežejo ali vršilca dejanja ali prizadeto z dejanjem, imajo v svojem pomenju pomensko sestavino 'premikanja', ki zaradi vključenega 'samopremikanja' oz. 'samodelovanja' lahko ukinja povratni se, tako se vzpostavljajo razmerja Veter giblje/premika veje > Veje se gibljejo/premikajo (pogovarjalna različica je npr. *Veje gibljejo). Pri primerih kot bivati in čustvovati pa je vključena 'procesualnost', ki pa ni nič drugega kot posplošeno 'premikanje in spreminjanje'.

Podobna stavčnopovedna razmerja se lahko vzpostavljajo še z glagoli s se kot npr. Amortizirali so stroj : Stroj se je amortiziral, Angažirali so umetnika : Umetnik se je angažiral, Bočili so pločevino : Pločevina se je bočila ipd.

\subsection{Prostomorfemski glagoli z vidika pomenske razločevalnosti}

1.2.1 Glagoli s se nasproti istoizraznim glagolom brez se - primeri, ko je poleg 'samopremikanja' poudarjena še katera dodatna razločevalna pomenska sestavina samodelovanja. Poleg tipičnih parov premikati : premikati se, spreminjati : spreminjati se ipd. imamo tudi razmerja tipa delati : delati se 'pretvarjati se', igrati : igrati se 'neresno ukvarjati se'; v teh primerih je poudarjeno splošno razmerje 'obvladovanja česa' nasproti 'konkretna aktualizirana dejavnost', ki jo skupaj z osebkom aktualizira prav se $e^{1}$ se izraža z glagoli boksati : boksati se, drsati : drsati se, smučati : smučati se, voziti : voziti se, zaklinjati 'rotiti' : zaklinjati se 'prisegati' v primerih kot On boksa za 'obvladuje boks' (nasproti Trenutno/Ob sredah se boksa).

\footnotetext{
${ }^{1}$ Raba se ob glagolih v teh primerih aktualizira tako osebek kot njegovo dejanje.
} 
Najtipičnejši zaimenski/zaimkovni morfem je se/si z različno stopnjo pomenske izpaznjenosti. ${ }^{2}$ Visoka stopnja pomenske izpraznjenosti omogoča tudi izbirno uporabo, npr. oddaljiti se/si, premisliti se/si, upati si/se. In če predložni morfem $z$ dodatnim pomensko-izraznim izpostavljanjem t. i. vezljivih pomenskih sestavin glagola vezljivost uvaja oz. širi, jo zaimkovni morfem z zasedbo udeleženca - prizadeto/prejemnik oži:

upati $v$ uspeh/na rešitev - upati si/se dvomiti o uspehu/rešitvi, igrati nogomet s pomarančo - igrati se slepe miši z otroki: *igrati se šah na računalniku, premikati pohištvo po sobi-premikati se po sobi; privoščiti prijatelju počitnice - privoščiti si počitnice, seznaniti sodelavca z novostmi - seznaniti se z novostmi, želeti ljudem srečo - želeti (si) pijačo ipd.

1.2.2 Obglagolska predložna raba - pomenska razločevalnost med nepredložno in predložno rabo istoizraznih glagolov:

Benti ('jezi se') nad sinom : Benti ('preklinja') sina, Buljil ('napeto gledal') je vanj : Buljil ('napenjal') je oči, Čustvuje ('vznemirja se') zaradi izgube : Čustvuje ('podoživlja') izgubo, Igra ('kratkočasi/zabava') s kartami : Igra ('obvladuje') karte, Igra ('poskuša') na tomboli : Igra ('stavi') tombolo, Pridirkati ('z dirko prispeti') na prvo mesto : Pridirkati ('doseči') prvo mesto, Sope ('lovi se') za svežim zrakom : Sope ('lovi') sveži zrak, Sune ('hipno trzne') z nogo : Sune ('hipno premakne') nogo, Trenirati ('vaditi') na parterju : Trenirati ('vaditi') parter, Trpeti ('prenašati') bolečine : Trpeti ('biti prizadet') zaradi bolečin ipd.

1.2.2.1 Predložna raba je neobvezna pri določenih glagolih, ki v svoji pomenskosestavinskosti že vključujejo 'namenskost' ali 'ciljnost' ali sploh usmerjenost na določeno vsebino, primeri za $n a$ in $z a$ :

čakati (na) vlak, gledati (na) oblake, igrati (na) piščalko, odgovoriti (na) vprašano $(R d)$ : odgovoriti (na) vprašanje(Pd), paziti (na) otroke/zdravje, pritiskati (na) gumb, streljati (na) sovražnika, zadeti (na) oviro; loviti (za) rokav, popasti (za) nogo, poterjati (za) denar, prositi $(z a)$ pomoč.

${ }^{2}$ Raba pa potrjuje, da prostomorfemski se/si ni nikoli pomensko povsem izpraznjen ('povratnost' je stalna sestavina), zato ga glede na njegov (razločevalno)pomenski prispevek k pomenskosestavinskosti glagola delim na a) se 'samopremikanja' v premikati se (nasproti: premikati koga/kaj), utopiti se (nasproti: utopiti koga/kaj), zgubiti se (nasproti: zgubiti koga/kaj) ipd., b) se 'samodelovanja' v razdajati se (nasproti: razdajati kaj), najesti se (nasproti: jesti kaj), dolgočasiti se (nasproti: dolgočasiti koga) ipd., c) se 'stanja (počutja)' v bati se (nasproti: strašiti koga/kaj), veseliti se (nasproti: /raz/veseliti koga), jokati se, kesati se, kujati se, naveličati se, počutiti se, smejati se, zdeti se ipd., č) se 'pojavnosti' v daniti se, svitati se, temniti se, kolcati se (komu), zehati se (komu) ipd., d) se 'splošnovršilske navajenosti/navadnosti' v primerih kot Tod se hodi na Triglav ipd. 


\title{
1.3 Dvoja (predložna ali brezpredložna) vezava
}

Dvojo (predložno ali brezpredložno) vezavo omogoča dovolj široka pomenskost glagola - ko lahko izbiramo med njegovimi pomeni; ${ }^{3} \mathrm{v}$ teh primerih gre za glagole oz. glagolske pomene, ki predvidevajo vsaj tri potencialne/možnostne udeleženske vloge s tremi udeleženci, od katerih je lahko eden neizražen, ker je sestavni del glagola ali izraženega (sestavljenega) udeleženca. Včasih določeni udeleženec lahko nastopa v dveh udeleženskih vlogah, ki se vsaj delno prekrivata oz. vzajemno dopolnjujeta - npr. prizadeto $z$ dejanjem se lahko vsaj delno prekriva $z$ izhodiščnim mestom dejanja ali s ciljem dejanja. Izbira udeleženca pa vzvratno vpliva tudi na izbiro določenega glagolskega (skladenjskega) pomena v okviru istega glagolskega leksema, npr. izčistiti 'odstraniti/očistiti' madež z obleke : izčistiti 'odstraniti' madež : izčistiti 'očistiti' obleko ipd. Podobna vezljivostna razmerja so še v primerih:

\begin{abstract}
dotočiti pijačo 'doliti' : dotočiti 'napolniti' kozarec, doliti vino : doliti kozarec, izmiti 'očistiti' rane : izmiti 'odstraniti' umazanijo iz rane, izpiti 'izprazniti' kozarec : izpiti 'odstraniti' vino iz kozarca, izčrpati vodo iz vodnjaka: izčrpati vodnjak, izčistiti madežz obleke : izčistiti obleko, izpiti vino: izpiti kozarec, izcediti sok: izcediti limono, izčistiti madež z obleke : izčistiti obleko, izkrtačiti prah iz obleke, izkrtačiti obleko, izpihati cevi : izpihati prah iz cevi, izterjati denar izlod ljudi : izterjati denar, nabasati jabolka $v$ košaro : nabasati košaro, oplesti ličje okrog steklenice : oplesti steklenico, oluščiti kožico s fižola : oluščiti fižol, odviti pokrov od steklenice : odviti steklenico, odkrhniti kos od krede : odkrhniti kredo, izpleti plevel : izpleti pšenico, iztrgati zvezek : iztrgati liste iz zvezka, naliti juho na krožnike: naliti krožnike, nametati misli na papir, nametati na papir, natlačiti jabolka v košare: natlačiti košare, vplačati prvi obrok za nov avtomobil : vplačati (za = 'ohranja sestavinsko razmerje') nov avtomobil, vrezati navoj (v kovino), posaditi gredo (z radičem), vskočiti (z dodatno kitico) pri zadnji pesmi, natovoriti voz (s pridelki), dognojiti posevke : doliti bencin : doliti/naliti kozarec, nasuti/dosuti : dosipati moko v vrečo : dosoliti, dotočiti/natočiti vodo: dotočiti/natočiti kozarec, dovesti razpravo do sklepa, dovesti ga do zdravnika, prikositi/dokositi do meje, namazati kruh : namazati marmelado : primazati ga, pripéti slavo/dovolj denarja : pripéti do ceste, zamešati testo : zamešati sestavine $v$ testo, zradirati papir : zradirati črte na papirju, zasaditi/posaditi gredo : zasaditi zelje na/v gredo, zarezati (črte v) drevo, zamazati deblo (s smolo) ipd.
\end{abstract}

\subsection{Posebnosti povedkovodoločilne (kvazi)vezljivosti}

Posebnost so vezljivi neizglagolski pridevniki. V okviru povedka oz. povedkovodoločilne vezljivosti je treba omeniti omejeno skupino izglagolskih in neizglagolskih pridevnikov, ki označujejo telesna in duševna stanja. In če je pri izglagolskih pridevnikih vezljivost posledica izhodiščnega glagolskega pomena, je pri neizglagolskih pridevnikih vezljivost posledica dinamičnega

\footnotetext{
${ }^{3} \mathrm{~V}$ slovensko jezikoslovje je razlikovanje med dvojo vezavo (z možnostjo izmenične uporabe dveh različnih sklonov) in dvojnično vezavo (z možnostjo hkratne uporabe dveh sklonov) v začetku 80-ih let prejšnjega stoletja vnesel Janez Dular in to tudi natančno uporabljal v svojih razpravah.
} 
pomena pomensko sorodnih glagolov - gre predvsem za stanjske pridevnike s prevladujočim razmernostanjskim skladenjskim pomenom (ki ga dodatno potrjuje še prostopredložnomorfemska raba): a) meritve/mere: biti oddaljen od (koga/česa), biti prisoten (pri kom/čem), biti skupen (komu/čemu), biti prost/ poln (koga/česa), biti odprt (za koga/kaj); b) primerjave: biti isti/enak (kot kdo/ $\mathrm{kaj} / / \mathrm{s} \mathrm{kom} / \mathrm{čim})$, biti enak za (koga/kaj), biti odvisen od (koga/česa), biti podoben (komu/čemu); in c) vrednotenja lastnosti/stanja: biti očiten/jasen/znan (komu), biti zmožen (česa), biti nagnjen k/h (čemu/komu), biti radoveden za (koga/kaj), biti ponosen na (koga/kaj), biti nujen/obvezen/primeren/upravičen/pomemben za (koga/kaj), biti izkušen/zadovoljen/nepošten/pravičen/ljubezniv s (kom/čim).

1.4.1 Povedkova samo stavkotvorna neudeleženska (in zato) neprava vezljivost v vremenskih povedih poleg stavkotvorno enodelnih izrekov - povedi tipa Dežuje, Lije, Piha ipd. ${ }^{4}$ omogoča kar nekaj samo navidezno dvodelnih stavkotvornih različic Dež je / Dež gre/pada, Dež lije, Veter piha ipd. ${ }^{5}$ Pri vremenskih brezosebkovih/brezosebnih ${ }^{6}$ stavkih je pomenskopodstavno/propozicijsko samo

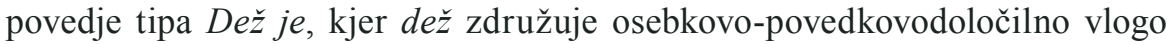
(tj. združljivost/kompatibilnost oz. medsebojno odvisnost osebkove in povedkovodoločilne vloge, tako da je osebkova samo formalnostavkotvorna vloga, povedkovodoločilna vloga pa je hkrati povedkovniška pomenskoskladenjska kategorija s povedkovim pomenom in lastnostmi (Vidovič Muha 2000: 124, 125), kar se tudi dovolj eksplicitno združuje v primerih kot Dež pada-Pada - Padalo je/bo - Dež je /bill - Deževno je /bilo/, Mraz je /bilo/ - Mrzlo je /bilo/ ipd.), vključena je lahko še nenujno upovedena okoliščina.

${ }^{4}$ V primerih tipa Dežuje, Rosi, Grmi A. Vidovič Muha (2009: 251) govori o stavkotvorni (levi) vezljivosti, ki je notranja oz. zakrita in se lahko eksplicitno razvezuje v *Dež dežuje, *Rosa rosi, *Grom grmi ipd., in s tem v zvezi posledično izpeljuje z vezljivostnega vidika relevantno trditev, da $»$ v tem smislu ne vzdrži trditev o nevezljivih glagolih«.

${ }^{5}$ Nova slovenska skladnja J. Toporišiča $(1982: 82,83)$ tovrstne povedi pomenljivo obravnava pod poglavjem nevezljivi in hkrati seveda tudi neprisojevalni glagoli, vendar vse naštete vremenske povedi v nadaljnji krajši razlagi ne obravnava kot neprisojevalno in samo slovničnoformalno stavkotvorne, temveč dopušča t. i. prvotno ali drugotno /ne/ prisojevalnost. Odpiranje možnosti prvotne in drugotne prisojevalnosti pa le dodatno opozarja na spremembo glagolskega pomena v povedju oz. na pomensko- in strukturnoskladenjsko spremembo povedka sploh.

${ }^{6}$ Pridevnik brezosebkov poudarja stavkotvorni vidik in stavkotvorne zmožnosti brez pravega udeleženskega osebka, temveč samo s končniško obliko za tretjo osebo ednine srednjega spola $-\mathrm{s}$ t. i. formalnim osebkom; pridevnik brezosebni pa se v prvi vrsti nanaša na brezosebni glagol brez konkretne osebe oz. brez pravega konkretnega osebka in zato tudi brez osebila oz. končniškega morfema (za izražanje oseb oz. osebka), ampak ima za izražanje samo oblikovne/formalne določnosti (na samo izrazni ravnini), tj. končniško obliko za tretjo osebo ednine, ki v zloženih oblikah izraža oz. pokaže tudi srednji spol - to so tretjeosebne (formalnoosebkove) glagolske oblike (nasproti brezosebnim glagolskim oblikam). 


\section{Posebnosti pri vezljivih udeležencih oz. določilih}

2.1 Tožilniška vezava pogosto naznanja vsebinskega udeleženca (nasproti predložnim sklonom, ki izražajo pretežno okoliščine, npr.:

Bije ('udarja') po mizi : Ura bije ('naznanja') polnoč, Bobna ('udarja') s prsti : Bobna ('igra') koračnico, Igra ('stavi') na loteriji: Igra ('obvlada') tombolo, Teče ('goji/trenira') maraton, Pritekel/Prismučal ('dosegel') je zlato medaljo ipd.

\subsection{Nakazane težnje $v$ tožilniško vezavo}

Težnje v tožilniško vezavo so nakazane pri glagolih s prevladujočimi pomenskimi sestavinami 'voditi, usmerjati, uravnavati' navadno imajo ali vsaj dopuščajo tožilniško vezavo, npr.:

sprehajati se s psom (prizadeto z dejanjem) 'voditi psa na sprehod' : sprehajati psa, upravljati s premoženjem (vsebina dejanja) : upravljati premoženje, upravljati s strojem (sredstvo dejanja) : upravljati stroj ipd.

Neke vrste prehod med neudeleženskimi in /iz/udeleženskimi obpovedkovimi dopolnili so primeri, kjer vsebinski udeleženec propozicijsko natančneje lastnostno oz. načinovno opredeljuje povedkov glagol, npr. iz športa On plava kravl in metuljčka (nasproti že lastnostno rabljenim On drsa posamezno / v paru < drsati kot posameznik / drsati s kom v paru). Že pravo udeležensko določilo pa je v primeru Vozi formulo ( $<$ Vozi se s formulo.).

\subsection{Nedoločniško in namenilniško določilo}

Vezava nedoločnika kot nesklonskega določila z neko »notranjo predikacijo« je priznana tako v slovenistiki kot širše v slavistiki. Nedoločnik se uporablja lahko tudi nevezavno, npr. Tukaj ostati ni varno, medtem ko je raba namenilnika lahko samo vezavna, v nasprotnem primeru gre za izpust vodilnega glagola, npr. Takoj spat! Vezava nedoločniških določil gre v smeri glagolske popolnosti. Z vidika stavčnega vzorca so glagoli z nedoločniškimi določili dvovezljivi. Vsa nadaljnja vezljiva nedoločniška določila pa niso več neposredno vezljivostno odvisna od izhodiščnega glagola, zato lahko govorimo le o razširjenem prostem stavku, to so primeri kot Pripravlja se govoriti o aktualnih problemih.

\subsection{Posebnosti osebkovih in orodniških vezljivih določil}

\subsubsection{Osebkove udeleženske vloge}

Osebek lahko označuje različne udeleženske vloge, ki glede na to ali so a) prvotne osebkove udeleženske vloge ali b) drugotne osebkove udeleženske vloge 
izražajo a) izhodiščne stavčne zgradbe ali b) pretvorjene/drugotne stavčne zgradbe. Prvotne osebkove udeleženske vloge so vršilec/povzročitelj/pobudnik $\left(\mathrm{V} / \mathrm{Pv} / \mathrm{Pb}_{\mathrm{d}}\right)$ ob glagolih tipa spreminjati/zažigati/vzpodbujati in nosilec dejanja/ dogajanja/procesa/stanja $\left(\mathrm{N}_{\mathrm{d} / \mathrm{dog} / \mathrm{p} / \mathrm{s}}\right)$ ob glagolih kot teči/dogajati se/spreminjati se/bivati ipd. Drugotne osebkove udeleženske vloge pa so prizadeto/prejemnik/ sredstvo/rezultat pri dejanju $(\mathrm{Pr} / \mathrm{Pre} / \mathrm{S} / \mathrm{R})$ v pretvorjeni povedi, npr. iz izhodiščnega stavka Anica $(V d)$ stavi vazo $\left(P r_{d}\right)$ na mizo v Vaza $\left(P r_{d}\right)$ je stavljenal se stavi na mizo (tj. potrpnjenje proti stanju Vaza (Ns) stoji na mizi) in v Vaza $\left(P r_{d}\right)$ je postavljena na mizi (postanjenje).

Določenim udeleženskim vlogam in določenim določilom na izrazni ravnini pa ustrezajo samo udeleženci z določenimi pomenskimi lastnostmi (Daneš 1987: 60, 61). Tako je npr. uporaba udeleženca s pomenskimi sestavinami živo ${ }^{+}$, človeško ${ }^{+}$v orodniku nesmiselna, npr. Pavel je zaprl okno : Okno se je zaprlo s Pavlom* (možna smiselna razlaga $s$ Pavlom je, da je sovršilec dejanja-poleg še enega neizraženega vršilca). Primera Veter je zaprl okno: Okno se je zaprlo z vetrom, pa kažeta, da pri naravnih pojavih lahko govorimo o nadomestnih vršilcih dejanja s pomenskimi sestavinami kot živo ${ }^{-}$, naravno ${ }^{+}$(pravi povzročitelj ni izražen), zato je izražanje z orodnikom možno in izraža nekakšno naravno sredstvo dejanja. Sicer pa se s sklonsko uporabo (npr. imenovalnik ali orodnik) v okviru osebka jasno izrazi tudi vršilskostna hierarhija oz. stopnja vršilskosti ${ }^{7}$, npr. Janez (Vd) je razbil okno : Kladivo (Sd) je razbilo okno (pomenski prenos oz. metonimija) : Janez (Vd) je razbil okno s kladivom (Sd).

Iz povedanega sledi, da ima osebek, kljub temu, da lahko izraža različne udeleženske vloge, stalno stavkotvorno ujemalnoprisojevalno razmerje. Izražanju z neimenovalniškimi določili (t. i. logični osebek) nasprotuje že utemeljitelj

\footnotetext{
${ }^{7}$ V zvezi z razširjanjem območja vršilskosti se zlasti v angleški in ameriški jezikoslovni literaturi omenja t. i. ergativno razmerje (ergativ = osebek prehodnega glagola, tj. ergativne zgradbe so prehodne), ki je obenem tudi nekakšno vzročno-posledično in oziralno razmerje med pobudnikom/povzročiteljem dejanja (lahko je eden ali pa jih je več) in vršilcem/nosilcem dejanja. Torej se poleg vršilskosti 'to do' izpostavi tudi vzrok dejanja oz. pobudnika 'make to do' (o tem M. A. K. Halliday ${ }^{2} 1994:$ 163-164, 169-172). Tako se navadno razmerje Janez (vršilec dejanja) brca žogo (predmet/cilj dejanja) lahko spremeni v Marko (pobudnik) povzroča/spodbuja, da Janez (vršilec) brca žogo (prizadeto). $\mathrm{Z}$ izpustom enega izmed delovalnikov znotraj vršilskosti se poruši vzročno-posledično razmerje, $\mathrm{s}$ tem pa se spremeni tudi pomen sporočila v Marko brca žogo.

$\mathrm{O}$ ostankih ergativnosti $\mathrm{v}$ določenem jeziku lahko govorimo vzporedno $\mathrm{z}$ ohranjanjem leksikalnih razlik neprehodnosti in prehodnosti. Skladenjska definicija ergativnosti pa osebek prehodnega dejanja pojmuje drugače kot osebek neprehodnega dejanja, predmet prehodnega dejanja pa enako kot osebek neprehodnega dejanja - v ergativni tipologiji je ergativni stavčni vzorec zgled za prehodni stavek, absolutni stavčni vzorec pa zgled za neprehodni stavek. Zmožnost t. i. ergativnih glagolov je, da isto dejanje lahko opišejo s stališča povzročitelja ali s stališča prizadetega, tj. da se lahko uporabljajo prehodno ali neprehodno, npr. upirati se, zapreti (se), blokirati (se), raziti se, hiteti, eksplodirati, napihniti (se), odtajati (se), razveseliti (se); ergativni glagoli imajo v desni vezljivosti lahko prislovna določila, npr. oditi, izstopiti, vstati, izluščiti se, vzpenjati se, spustiti se, nalepiti/prilepiti se ipd.
} 
pomenskega sklona Ch. J. Fillmore, ki v skladu s tvorbeno-pretvorbeno teorijo osebek opredeljuje kot površinskoizrazno kategorijo samo v okvirih pomenske delitve osebkovih imenovalnikov. ${ }^{8}$ Fillmorjevo osebkovo imenovalniško teorijo podpira tudi stavčnočlenska analiza, ki vršilce dejanja ali nosilce dejanja/stanja označuje kot imenovalniške osebke ali kot neimenovalniške predmete (kamor sodi tudi logični/smiselni osebek).

G. Helbig pa s stavčnočlenskega vidika z upoštevanjem slovničnih kategorij neživo in nečloveško razširi obseg osebkovih vlog od t. i. normalnega osebka na netradicionalne vsebine osebkovih vlog. ${ }^{9}$

Sistemsko bolj dodelana glede na vrstnost delovanja in sorazmerno nova, prilagojena računalniškim zmožnostim obdelave, je novejša delitev udeleženskih vlog v slovaškem jeziku10.

${ }^{8}$ Ch. J. Fillmore (1968: 6) deli osebkove imenovalnike na a) nominative of personal agent, b) nominative of patient, c) nominative of beneficiary, č) nominative of affected person in na d) nominative of interested person, kar je v slovenščini imenovalnik vršilca dejanja (Mož je brcnil žogo), imenovalnik prejemnika dejanja (Mož je dobil udarec), imenovalnik koristnika (Mož je dobil darilo), imenovalnik naklonjenega osebka (Mož jo ljubi) in imenovalnik obravnavanega osebka (Mož ima črne lase). Na Ch. J. Fillmora se je pri določanju 'pomenske valence' ruskega jezika opiral Ju. D. Apresjan $\left({ }^{2} 1995\right.$ : 25-26, 125-126), ko je po Fillmorovem vzorcu globinskih sklonov izdelal 9 osnovnih udeleženskih vlog za ruščino in 25 natančnejših različnih možnih tipov pomenske vezljivosti (glede na pomensko različne udeležence).

${ }^{9}$ Gl. G. Helbig, J. Buscha (1984: 560-562). Osebkove možne (prvotne in drugotne) udeleženske vloge so: vršilec dejanja (Mati pere), vzrok dejanja (Voda je spodkopala hišo), nosilec dejanja (Roža je odcvetela/Fant se je razvil), nosilec stanja (Peter ima vročino/Perilo je suho), udeleženec (sopovzročitelj) dejanja ali stanja (Mleko vre/Peter je poškodovan), rezultat dejanja (Hiša bo zdaj zgrajena), naslovnik (Učenci so dobili pomoč), sredstvo dejanja (Nož reže kruh), mesto dejanja (Zaboj je poln knjig), nosilec telesnih procesov (Prst mi krvavi), nosilec duševnih procesov (Igralec se jezi zaradi poraza), udeleženec (sopovzročitelj) duševnih procesov (Neurje je prestrašilo otroka), nosilec razsodbe/spoznanja (Voznik je ocenil položaj), udeleženec razsodbe/spoznanja (Ta problematika je za znanstvenika nova), nosilec zaznave/opažanj (Mati opazuje otro$k a$ ), udeleženec zaznav/opažanj (Njegov klic na pomoč je bil sprejet), nosilec (priredni/ podredni) razmerij (Sekcija ima dva oddelka/Dva oddelka spadata v to sekcijo), označevalec obstajanja/navzočnosti (Včeraj se je pripetilo hudo neurje), nameščeni udeleženec (Knjige so na polici).

${ }^{10}$ E. Páleš (1990) ločuje »agens« (živega povzročitelja in vršilca dejanja, npr. Sosed je kupil avto, Voznik vozi avto), za neciljno delovanje ima »elementiv« (neživi prapovzročitelj dejanja oz. naravna sila, npr. Veter je razbil okno, Reka je očistila korito), za povratno dejanje ima "procesor« (svojo dejavnost usmerja nase Kmet kosi (travo)), "produktor« (živi ali neživi proizvajalec ostaja nespremenjen in njegovo dejanje ne prizadeva nobenega predmeta, npr. Sonce sveti, Oče kriči, včasih je nosilec lastnosti, npr. Rože dišijo), »statual« (nosilec fizičnega ali psihičnega stanja, npr. Micka je zardela, Grad je opustošen; v vlogi osebka v govornih procesih avtor ločuje »editor« (govorca oz. tvorca govornega ali pisnega izdelka), v procesih zaznavanja »perceptor« (npr. Dekle je zavonjalo duh rože, v procesih spoznavanja »kognizant« (npr. Faust se je zamislil nad življenjem), v čutnih ali čustvenih procesih »afektor« (živi preživljalec, npr. Deček se je 
2.4.1.1 Določanje osebka $z$ upoštevanjem pomenske sestave povedi in členitve po aktualnosti ${ }^{11}$ presega meje leve vezljivosti. Težave pri določanju osebka se najbolj jasno odkrivajo v BITI-stavkih (Kunst Gnamuš 1989/90). Pri nas je bilo ugotovljeno, da v takšnih primerih vlogo osebka pripišemo tisti besedi, ki v nezaznamovanem besednem redu zaseda vlogo izhodišča. Drugo merilo pa je pomenski dejavnik, ki vlogo osebka prisoja besedi s pomensko lastnostjo 'konkretno' (proti besedam z abstraktnejšimi pomeni), npr. v Ta knjiga je resnica je osebek ta knjiga. Tudi v angleščini je močna težnja zliti izhodišče z osebkom (Halliday ${ }^{2}$ 1994: 117), sicer pa je osebek = oznaka vsebine (Token, H. 129) in obvezno določilo = ovrednotenje (Value, H. 129), tako da veljajo ustaljena razmerja osebek : določilo, določano : določujoče, oznaka vsebine : ovrednotenje. $\mathrm{V}$ istovetenjskih BITI-stavkih so vloge opredeljene kot Janez (osebek = določana vsebina) je eden izmed najbogatejših ljudi (povedkovo določilo = določujoča vrednost); iz tega primera lahko izpeljemo tudi stavka Janez (določani osebek) je najbogatejši (določujoče povedkovo določilo), kjer je istovetnost je izražena v smeri ovrednotenja vloge, nasproti Najbogatejši (določano povedkovo določilo)

prestrašil psa), v procesih pripisovanja lastnosti »atributant« (npr. Zemlja je okrogla), v procesih istovetenja »identifikant« (npr. Janez je postal vodja).

${ }^{11} \mathrm{Z}$ večjim poudarjanjem in upoštevanjem členitve po aktualnosti pa se logičnemu osebku in slovničnemu osebku dodaja še psihološki osebek (nanj opozarja M. A. K. Halliday (1970), v ruski vezljivostni teoriji pa je označen kot psevdosubjekt, gl. I. B. Levontina (1996: 49)). V primerjavi s prvima dvema je besedilna prvina in hkrati tudi eden izmed nosilnih elementov sporočila - je del sporočilnega jedra ali izhodišča. Določitve osebkov s stališča besedilne teorije oz. teorije govora pa so drugačne. Po Hallidayu ( ${ }^{2} 1994$ : 30, 44, 72, 80, 93, 163-174, 285-286) npr. Mati (slovnični osebek) mi (logični osebek) je dala ogrlico. Ogrlica (psihološki osebek) je bila pozneje spravljena pri hčerki. Pozneje smo ji (psihološki osebek) vdelali še napis. Brez upoštevanja besedila in sobesedila pa bi bila pričakovana določitev: Ogrlica (slovnični osebek) $j i$ (logični/smiselni osebek) je všeč. V besedilu (in mogoče z upoštevanjem še sobesedilnih elementov) pa je ogrlica lahko tudi psihološki osebek.

Tako stavčnočlenska oznaka osebek označuje tri krovne osebkove vloge na različnih jezikovnih ravninah - v sporočilu se kot besedilna/kontekstna sestavina pojavlja t. i. psihološki osebek, ki je glede na govorčevo zavest tudi nezaznamovano izhodišče sporočila oz. tema; slovnični osebek vzpostavlja prisojevalno razmerje tudi z nečloveškim ali z neživim vršilcem ali nosilcem dejanja; t. i. tipični/navadni osebek v imenovalniku pa označuje človeškega vršilca dejanja. Neimenovalniški logični/smiselni vršilec dejanja je površinskoizrazno predmet. V stavku so lahko vse te tri pomenske vloge označene z istim osebkom ali z različnimi osebki ali s predmetom, npr. Vojvodinja (psihološki/ slovnični/logični osebek) je dala moji teti ta čajnik, Moja teta (psihološki/slovnični osebek) je dobila ta čajnik od vojvodinje (predmet), Ta čajnik (psihološki osebek) je vojvodinja (slovnični/logični osebek) dala moji teti, Ta čajnik (psihološki osebek) je moja teta (slovnični osebek) dobila od vojvodinje (predmet). Glede na razporeditev osebkovih pomenskih vlog K. F. Sundén (1916) ločuje še logične in nelogične predikacije. Kot lastnost nelogičnih predikacij, ki so izpeljane iz logične predikacije $\mathrm{z}$ isto pomensko zgradbo, navaja nesovpad logičnega in slovničnega osebka. Tako, da je pomembna logična vrednost slovničnega osebka v predhodni (neizpeljani) logični predikaciji (gl. primere zgoraj). 
je Janez (določujoči osebek) $\Rightarrow$ istovetnost je izražena v smeri oblikovanja vsebine. Poleg tega pa se pokaže, da je določujoče v povedi vedno tudi pomensko poudarjeno, kar pa uvaja tudi zaznamovani besedni red.

\subsubsection{Orodniško vezljivo določilo}

S splošnoslovanskega oz. primerjalnoslovanskega vidika je za začetek potrebna opomba, da je v slovenščini nujna uporaba predloga oz. predložnega glagolskega morfema. Za osnovni in izhodiščni pomen je označen spremstveni pomen. ${ }^{12}$

Pri izražanju pomensko nujne spremstvene okoliščine ob nepolnopomenskih glagolih sta brezpredložni orodnik v povedkovodoločilni rabi, npr. Imenuvali su Napoleona cesarom, Detetom postajem, nadomestila imenovalnik ali (predložni) tožilnik, kar pa sporočilno ni isto - On je bil sodnikom lahko prevajamo kot On je bil za sodnika (začasna/pridobljena lastnost) nasproti On je bil sodnik (trajna lastnost). ${ }^{13}$

Z vidika stavčnočlenskosti orodnik izpostavlja najtežje določljivo razmerje med (predložnim) predmetom in prislovnim določilom/dopolnilom načina. ${ }^{14}$

${ }^{12}$ F. Kopečný (1973: 246-249) orodniški spremstveni pomen označuje tudi s slovenskimi zgledi kot Kdor se z volkovi pajdaši, mora z njimi tuliti; potovati s kom, s praznimi rokami priti. V okviru spremstvenega pomena izpostavi predvsem izražanje vsebine, npr. hrnec s vodou ('lonec z vodo'), lopata s držadlem ('lopata z ročajem'), bogat z žitom, in izražanje načina, ki je predstavljeno predvsem s pojmovnimi samostalniki in s telesnimi deli, npr. za slovenščino s strahom pogledati kam, s praznimi rokami priti. $\mathrm{V}$ tesno povezanost s spremstvenim pomenom postavi tudi izražanje sredstva in orodja, kjer so tudi samostalniki s pomeni telesnih delov, npr. s palicami biti, s kolom udariti koga, igrati se s puško: Konj se brani s krepko nogo. Pri nas A. Bajec (1959: 107-109) v zvezi z uporabo predloga oz. predložnega glagolskega morfema z/s ugotavlja, da je tudi za slovanske jezike prvotna uporaba »s sociativnim intrumentalom, ki pomeni skupnost, združenje /.../.«In še pomembna pripomba pri stavčnočlenski uporabi predložnega orodnika $(\mathrm{Oz} / \mathrm{s})$, da je vsako sredstvo nekakšna spremljajoča okoliščina in zato »/.../ se ni čuditi, da je poleg golega orodnika (instrumentala) jel nastopati v takih primerih $\mathrm{s}$ + družilnik (sociativ) /.../.« Čeprav je opozorjeno na ločevanje med družilnikom (tepsti se $s$ fanti) in orodnikom (tepsti se s cepci), pa niso obravnavane stavčnočlenske razlike predložnih samostalniških zvez med $Z$ njim so dobili mogočnega zaveznika $\Leftrightarrow$ s kom? - z njim), Vozniki se že peljejo z balo $(\Leftrightarrow \mathrm{s}$ čim? - z balo) : Prišel je s praznimi rokami ( $\Leftrightarrow$ kako? - s praznimi rokami), Z veseljem vam ustrežem $(\Leftrightarrow$ kako?).

${ }^{13}$ Zgodovinski pregled uporabe in obravnave predlogov oz. predložnih morfemov v slovenskem jezikoslovju imamo v razpravah M. Orožen (1975) in I. Orel Pogačnik (1993), ki potrjujejo tezo, da se je predložni sistem v smislu sodobne knjižne norme izoblikoval šele konec 19. stoletja in se tako približal današnji.

${ }^{14} \mathrm{~V}$ drugi polovici sedemdesetih let $\mathrm{v}$ okviru vezljivosti v sodobni poljščini npr. D. Buttler (1976: 163-186) pri orodniku v skladenjski vlogi predmeta (narzędnik w funkcji dopełnienia) z vidika glagolskega pomena govori o bližjem dopolnilu (dopełnienie bliższi) - tj. o obveznem določilu. Za orodnik v skladenjski vlogi prislovnega določila (narzędnik w funkcji okolicznikowej) pa z vidika glagolskega pomena govori o okoliščinskih pomen- 
Tako npr., če je pomen udeleženega sredstva/orodja ${ }^{15}$ namesto z orodnikom lahko izražen s še kakšnim drugim pomensko enakovrednim sklonom, je takšno sredstvo/orodje stavčnočlensko (predložni) predmet, npr. posuti cesto s peskom : posuti pesek na cesto (Orešnik 1994: 42). V tem primeru je udeleženec bolj snov kot sredstvo in je zato še bolj upravičeno predmet. ${ }^{16}$ Isti orodniški udeleženec lahko glede na glagolski pomen prevzame vlogo snovi ali sredstva, sredstva ali prizadetega npr. polniti kad z vodo (snov) : umiti kad z vodo (sredstvo), obmetavati ograjo s kamenjem (sredstvo/prizadeto).

Zadrege pri stavčnočlenskih opredelitvah izraža tudi oznaka prislovno določilo orodja/sredstva (Orešnik 1994: 42).

Razlika med sredstvom dejanja (Sd) in orodjem dejanja (Od) je ta, da sredstvo (Sd) pri dejanju spreminja tudi svoje lastnosti oz. za uresničitev določenega dejanja lahko prispeva del sebe, orodje (Od) pa tudi po koncu dejanja ostaja nespremenjeno. Sredstvo in orodje dejanja imata kot določili tudi z vidika strukturnoskladenjske hierarhije različni oblikoslovnoskladenjski vlogi (prim. Apresjan 21995: 128), npr. Šivati hlače s črno nitjo na šivalnem stroju ipd.

skih razmerjih (określone znaczenie relacyjne) in o slabi vezavi (slaba rekcja). V poglavju o predložnih zvezah $-V$. Konstrukcje przyimkowe (187-215) v primerih predložnega glagolskega morfema ali (predložnega) predmeta govori o 'predložni vezavi glagola' (rekcja przyimkowa czasowników), pri predložnih prislovnih določilih pa o okoliščinski vezljivosti (określona walencja). Orodnik kot (predložno)sklonsko določilo, ki označuje prehodni tip med vezljivostnimi in nevezljivostnimi stavčnimi členi, natančneje in primerjalno uporabno tudi za slovenščino obravnava Mluvnice češtiny - Skladba 3 (1987: 190-192).

J. Dular (1982: 191) navaja, da so ob orodniku najpogostejši predložni morfemi $z / s, z a$, pred, med, nad. Za predmetno stavčnočlensko vlogo orodnika J. Dular navaja pogoje: a) Orodnik izraža prizadeti predmet pri glagolih številnih pomenskih skupin (npr. glagoli, ki vežejo telesne dele (vrteti z očmi/z glavo), glagoli, ki se vežejo samostalniki, kot npr. ravnati s strojem; b) Orodnik izraža vsebinski predmet pri glagolih tipa ukvarjati se s tihotapstvom, obirati se z odhodom ipd.; c) Orodnik izraža razmerni predmet pri glagolih, ki izražajo solidarnost ali podobnost, npr. potrpeti z ljudmi, primerjati se s sorodnico ipd.

${ }^{15}$ Za sredstvo in orodje dejanja SSKJ v pomenskih razlagah uporablja tipski oznaki naprava (za večje, sestavljeno) in priprava (v ožjem pomenu tudi: orodje; za manjše, enostavnejše). Izraz sredstvo je nadpomenka za napravo in pripravo (ki vključuje tudi orodje in je namenjena za določeno delo). Tipski oznaki orodje in stroj sta v primerjavi z zgornjimi pomensko ožji, ker natančneje označujeta namenskost za določeno delo.

${ }^{16}$ J. Orlovský (21965: 372) zagovarja pravilo, da če je orodnik zamenljiv s tožilnikom, ima skladenjsko vlogo (predložnega) predmeta. Če pa orodnik ni zamenljiv s tožilnikom, ima skladenjsko vlogo prislovnega določila, npr. šúhat' nohami - šúhat' nohy $\Rightarrow$ (predložni) predmet. V slovenščini v pomenu 'drgniti' ali 'drsati' to ne gre, ker sta orodnik in tožilnik pomenskorazločevalna. Podobno še krútit' hlavou - krútit’ hlavu (v slovenščini se v pomenih 'vrteti, sukati, obračati' uporablja tožilnik, npr. vrteti glavo). 
Tudi za slovenščino zanimivo razpravljanje o orodniku po zgledu Fillmora je v članku Barbare Hall Partee..$^{17}$ Opozorjeno je na razmerja med a) vsebinskim predmetom $v$ tožilniku ali orodniku (the instrumental adverb) in med b) orodnikom, ki izraža orodje (the clearly instrumetal), npr. a) We loaded hay onto the truck, We loaded the truck with hay ('Na voz smo naložili seno, Voz smo naložili s senom') : b) We loaded the truck with hay with pitchforks (*'S senenimi vilami smo naložili voz s senom'). Ugotavlja, da bi v primeru a) težko govorili o prislovnem določilu v orodniku (the instrumental adverb), ker so pomeni pod a) pomensko zelo blizu povedku s tem, da je uporaba enkrat tožilnika in drugič orodnika pomenskorazločevalna, npr. Na voz smo naložili seno $(\Leftrightarrow$ 'ni nujno, da je voz poln') : Voz smo naložili s senom $(\Leftrightarrow$ 'voz je poln'). Pod b) pa je jasno izpostavljeno pomensko razločevanje med orodnikom kot vsebinskim predmetom in orodnikom, ki izraža orodje, npr. *S senenimi vilami (prislovno določilo orodja) smo naložili voz s senom (vsebinski predmet). Ista opažanja in isti pomenski premiki veljajo tudi za slovenščino.

Orodnik kot sredstveni predmet ali kot prislovno določilo orodja pretvorbeno določata E. V. Padučeva in R. I. Rozina (1993). Avtorici ugotavljata, da orodnik izraža sredstvo, ko ostaja poved smiselna tudi po površinskoizrazni pretvorbi orodnika v imenovalnik (orodnik > imenovalnik), npr. Dokumente je spel s sponko > Sponka spaja dokumente; če pa orodnik izraža orodje, poved po površinskoizrazni pretvorbi orodnik > imenovalnik ni več smiselna, npr. Dokumente je spel s spenjačem > *Spenjač spaja dokumente.

V primerih kot Ona je zagrnila okno z zaveso : Zavesa zagrinja okno zaradi zmanjšanja števila skladenjskih udeležencev po pretvorbi udeleženec zavesa združuje udeleženski vlogi vršilca in sredstva dejanja $(\mathrm{Vd} \cap \mathrm{Sd})$. Je potemtakem sredstvo dejanja vsak leksem, ki lahko sprejme tudi vlogo vršilca dejanja? Po zgornjih primerih bi lahko odgovorili pritrdilno.

Pretvorbe iz orodnika v imenovalnik ali tožilnik kot merilo za ločevanje med predmetnim in prislovnodoločilnim orodnikom (verjetno tudi pod vplivom Padučeve) navaja tudi D. Buttler (1976: 163-186).

2.4.2.1 Ob polnopomenskih glagolih ravnanja/upravljanja s pomenskima sestavinama 'premikanja' in 'sonahajanja/sopojavljanja' ima orodnik skladenjsko vlogo predmeta (s čim), če je glagolski pomen neposredno povezan s pomenom udeleženca. Med prvotnim glagolom in udeležencem torej ne sme biti še dodanega vmesnega premostitvenega glagola, npr. Preti s sekiro $>$ v pomenu 'pretiti s telesno poškodbo' (sekira je tu s stališča glagolskega pomena vsebinski predmet, zato je lahko izražena tudi v imenovalniku Preti mu sekira v prenesenem pomenu 'Preti mu telesna poškodba'). Drugače pa je v primeru Preti s sekiro s

${ }^{17}$ Gl. članek On the Requirement that Transformations preserve Meaning - Pogoji, da pretvorbe ohranjajo pomen v zborniku razprav Ch. J. Fillmorja in D. T. Langendoena (1971: 21). Ch. J. Fillmore (1968: 24-25) med opisom globinskih sklonov označi orodnik (instrumental (I)) kot sklon, ki izraža neživo silo ali predmet, ki je vključen v dejanje oz. ga določa glagolski pomen. 
premostitvenim glagolom udariti $z / s \mathrm{v}$ pomenu 'Preti, da ga bo udaril s sekiro' (sekira je tu s stališča glagolskega pomena orodje dejanja (Od), zato pretvorba iz orodnika v imenovalnik na površinskoizrazni ravnini ni smiselna *Preti mu sekira $($ sekira $=$ 'orodje')). Pretiti je tu šele v posrednem odnosu s sekiro, zato je v tem primeru s sekiro neobveznovezljivo prislovno določilo načina (kako?).

Zgornji primeri samo potrjujejo, da je pri stavčnočlenskem ločevanju med (predložnimi) predmeti in prislovnimi določili potrebno poleg slovničnega vidika upoštevati tudi sporočanjski vidik oz. predvsem členitev po aktualnosti. Tako npr. je pomenski poudarek na sekira, ko ta pomeni 'telesno poškodbo', v drugem primeru pa je pomenski poudarek na pretiti, saj sekira tu pomeni le 'eno izmed različnih orodij pri pretnji'.

Z vidika istorečja je v primeru sekati s sekiro izpis udeleženca sekira na prvi pogled čisto odveč, v resnici pa ima njen izpis pomenskorazločevalno vlogo $\mathrm{o}^{18} \mathrm{v}$ pomenu 'sekati s sekiro, in ne s kakšnim drugim rezilom' in je stavčnočlensko zato predmet.

Sploh pa je pomenskorazločevalna vloga stalna ob predložnomorfemskih glagolih z oslabljenim pomenskoskladenjskim pomenom, npr. Maha s sekiro (predmet), zato imamo v tovrstnih pomenih samo obveznovezljiva določila.

2.4.2.2 Kot (primerjalno) posebnost je potrebno omeniti vezavno družljivost ob glagolih premikanja, ki jo uvaja orodnik. V okviru glagolov premikanja ${ }^{19}$ imamo osnovna glagola iti in peljati $s^{20}$, ob katerih je prevozno sredstvo različno strukturnoskladenjsko oz. stavčnočlensko (kot prislovno določilo načina ali kot (predložni) predmet) opredeljeno. Tako se po predložni zvezi $z$ avtobusom $\mathrm{v}$ glagolski zvezi iti z avtobusom vprašamo s KAKO?, ker je predlog pomensko del predložnega prislovnega določila načina in zvezo lahko pomensko razgradimo v 'iti' v vozilu/avtobusu' $\Rightarrow$ iti kako?; vprašalnico primerjalno potrjuje glagolska zveza iti peš. Podoben primer je bežati s kolesom, ki ga pomensko razložimo kot 'hitro iti' + 'biti na kolesu' $\Rightarrow$ 'hitro iti, tako da si na kolesu' $\Rightarrow$ 'hitro iti' kako? $\Rightarrow$ bežati kako? $\Rightarrow$ predložna zveza $s$ kolesom je prislovno določilo načina.

V glagolski zvezi peljati se z avtobusom pa že glagol peljati se vključuje pomene 'iti + biti v vozilu', tako da je avtobus samó natančnejša pomenska določitev vrste vozila, in zato ima stavčnočlensko vlogo (predložnega) predmeta.

${ }^{18}$ Npr. v okviru glagolskih tvorjenk A. Vidovič Muha (1985: 49) obravnava tudi skladenjskopodstavno orodniško vezavo, kjer »glagolska tvorjenka poimenuje dejanje na podlagi pripomočka, sredstva, s katerim se dejanje opravlja /.../«.

${ }^{19}$ F. Daneš (1987: 88-119) pri glagolih premikanja govori o pomenskih sestavinah kot: samogib. +/- (samohyb $+/-)$, živo +/- $($ anim $+/-)$, orod.+ (instr + ), narav. + (natur +$)$ ipd.

${ }^{20}$ Pri nas je o vezljivostnih posebnostih glagolov premikanja pisala I. Černelič Kozlevčar (1979), predvsem z vidika oblikovanja slovarskih pomenov in izbire ponazarjalnega gradiva. 
Sicer pa so ob procesnih in dogodkovnih glagolih premikanja ${ }^{21}$ lahko trdimo, da pomen prevoznega sredstva navadno združuje sredstvo in mesto dejanja ( $\mathrm{Sd}$ $\cap \mathrm{Md}$ ), npr. peljati se z avtobusom (Ju. D. Apresjan ${ }^{2}$ 1995: 128, 140). Prvotno orodniško sredstvo dejanja zaradi lastne aktivnosti oz. izvornosti dejanja lahko po metonimični/metaforični pretvorbi nastopa tudi v vlogi osebka. Navadno je to tehnični pripomoček, stroj ali naravna sila, še najbolj navadno pa je prevozno sredstvo, npr. Pripeljal se je z avtobusom, Avtobus ga je pripeljal (Páleš 1990: 35). Ta pretvorbena zmožnost sredstva dejanja nastopati v osebkovi vlogi ga, vsaj pogojno, uvršča v vezljivostno polje glagolov premikanja.

2.4.2.3 Glagolski pomen ustvari določeno udeležensko hierarhijo, posledica katere je strukturnoskladenjska hierarhija med določili - med predmeti in izsamostalniškimi prislovnimi določili.

Vzemimo, da sta izsamostalniška prislova ročno in strojno okoliščinski nadpomenki za delovalnike, ki označujejo orodje dejanja (Od) ali sredstvo dejanja (Sd). Če je ob istem glagolu poleg udeleženca $\mathrm{z}$ vlogo sredstva ali orodja smiselna uporaba izsamostalniškega načinovnega prislova strojno ali ročno, ki označuje način glagolskega dejanja, je samostalniški udeleženec stavčnočlensko (predložni) predmet, ki pomensko/predmetno natančneje določa način dejanja strojno/ročno. Če pa uporaba prislova strojno ali ročno ni smiselna, je takšen samostalniški udeleženec stavčnočlensko navadno del predložnega prislovnega določila načina. Glede na povedano so možne strukturnoskladenjske različice $\mathrm{z}$ določili: Piše (ročno/strojno) (kako?) s peresom/z računalnikom (s čim?), Piše s peresom/z računalnikom (kako?) proti dopolnilom: Računa s svinčnikom/z računalnikom (kako? $\Rightarrow$ prim. pog.: Računa peš).

$\mathrm{V}$ nasprotju z neživimi samopremičnimi delovnimi/prevoznimi sredstvi so abstraktni pojmi kot veselje, žalost ipd. neudeleženske sestavine (tj. ne spadajo $\mathrm{v}$ pomensko podstavo povedi). Povedkov glagol samo lastnostno opredejujejo to potrjujejo pretvorbe $\mathrm{v}$ izpridevniške prislove, npr. $Z$ veseljem se je odpeljal - Veselo se je odpeljal.

2.4.2.3.1 Razmerja med vršilcem dejanja (Vd) ali družilnikom (Dd) in orodjem (Od) so izražena v zgledih kot Se je odpeljal/je kopal / s prijateljem / s psom / $z$ lopato ('On in prijatelj/pes sta se odpeljala' / 'On in prijatelj sta kopala, tako da sta zarila lopati' (možna pretvorba iz orodnika v imenovalnik izraža vršilca dejanja ali družilnika). Medtem ko je primer *Lopata je kopala dokaz, da lopata z udeležensko vlogo orodja (Od) zahteva tudi vršilca dejanja (Pauliny 1943). Uporabljene besede prijatelj $(\mathrm{Vd} / \mathrm{Dd})$, pes $(\mathrm{Dd})$ in lopata $(\mathrm{Od})$ so samostalniška določila, stavčnočlensko pa predmeti.

Ko pa ima glagolski pomen zasedena že vsa svoja bistvena udeleženska mesta kot so vršilec dejanja, prejemnik in prizadeto z dejanjem, površinskoizrazno pa

${ }^{21}$ Takšno delitev glagolov premikanja povzemam po F. Danešu (1987: 88-119), v poglavju Vzorce se slovesy pohybu. 
je prenasičen z orodniki, npr. S sosedi (družilnik) so založili klet (prejemnik) $s$ premogom (prizadeto) z lopato (okoliščina), sta sredstvo ali orodje lahko samó okoliščinski dopolnili.

Udeležensko hierarhijo oz. hierarhijo udeleženskih vlog v stavčni povedi potrjuje tudi Fillmorova teorija o globinskih sklonih in sklonskih razmerjih, ${ }^{22}$ ko npr. osebek enkrat izraža vršilca dejanja (a), drugič pa orodje dejanja (b). V primeru, ko sta v povedi obe udeleženski vlogi, pa je osebek vršilec dejanja (c): a) John broke the window ('Ivan je razbil okno') : b) A hammer broke the window ('Kladivo je razbilo okno') : c) John broke the window with the hammer ('Ivan je razbil okno s kladivom'). Ker osebek lahko označujeta (po Fillmoru) dva različna globinska sklona (agentiv = pobudnik/vršilec glagolskega dejanja, je živo bitje : instrumental = sredstvo/orodje, je neživa sila ali predmet, ki povzroča glagolsko dejanje ali stanje), ju ni mogoče povezati v priredno zloženi osebek, npr. John and hammer broke the window ('Ivan in kladivo sta razbila okno'). Dokaz torej, da enakovrednosti prirednih sestavin ni mogoče razumeti samo strukturnoskladenjsko, ampak mora biti vedno upoštevan pomen teh sestavin (Kunst Gnamuš 1981: 121).

Pretvorbe tudi pokažejo, da je vloga sredstva dejanja (Sd) neposredno povezana z dejanjem (De), tako da sredstvo učinkuje na predmet, ne da bi pri tem moralo postati orodje - je samodelovalno. Zato sredstvo dejanja (Sd) lahko nadomešča vršilca dejanja (Vd). Orodje dejanja (Od) pa je samo posrednik med vršilcem dejanja $(\mathrm{Vd})$ in predmetom dejanja (Pd), zato ne more nadomeščati vršilca dejanja (Vd). Sredstvo proti orodju izraža tudi samodelovalne lastnosti.

Strukturnoskladenjsko oz. površinskoizrazno ločevanje orodnikov z udeležensko vlogo sredstva dejanja (Sd), orodja dejanja (Od) in vršilca dejanja (Vd) je $\mathrm{v}$ angleščini ${ }^{23}$ razlikovalno izraženo, predvsem v trpniku, s predložnim morfemom by za Sd in Vd in s predložnim morfemom with za Od, npr. I go to school by car ( $=\mathrm{Sd}$, 'V šolo grem $\mathrm{z}$ avtomobilom'), He was killed by a terrorist (= Vd, '(On) je bil ubit od teroristov') : You can cut the bread with that knife (= Od, 'Ti lahko odrežeš kruh s tem nožem'). To samó potrjuje samodelovalno zmožnost predvsem Vd, kot izvor delovanja se mu pridružuje še Sd, medtem ko je Od pasivni udeleženec dejanja. Primeri uporabe orodnika $+\mathrm{z} / \mathrm{s} \mathrm{v}$ trpniku pa kažejo, da samostalnik za predložnim morfemom by označuje predvsem Vd, ko pa tega ni, lahko tudi Sd/Od, npr. pri The window was broken /by a boy/by a ball proti The window was broken with a ball/*with a boy, kjer samostalnik za with $\mathrm{v}$ trpniku lahko označuje samo Od, v tvorniku pa tudi družilnik, npr. You're coming with us (Quirk idr. 1993: 160).

2.4.2.3.1.1 Posebnost je, ko v vlogi sredstva dejanja (Sd) nastopa človek ali pa samo deli telesa, npr. Božal ga je z očmi (s čim? $\Rightarrow \mathrm{z}$ očmi $=\mathrm{Sd}$; z možno

${ }^{22} \mathrm{O}$ tem Ch. J. Fillmore (1968: 22); pri nas pa s prenašanjem te teorije tudi O. Kunst Gnamuš (1981: 30>).

${ }^{23}$ Prim. R. Quirk idr., A Comprehensive Grammar of the English Language (201994: 559). 
pretvorbo Njegove oči so ga božale). Pretvorba samo še potrjuje del telesa oz. organ kot delujoči del osebka, zato v takšnih primerih govorimo o osebkovi vezljivosti, ki vključuje 'osebo' in 'vršilskost' (proti predmetni vezljivosti, ki vključuje 'predmet' in 'udeleženost' (po Apresjanu 21995: 165, 'sub'jektnaja valentnost in ob'jektnaja valentnost'), in ne o orodniški predmetni vezljivosti (prim. Apresjan ${ }^{2} 1995$ : 129). ${ }^{24}$ V. Kalenić (1970: 121) primere kot Streljao me je bijesnim očima označuje kot vzorčne zglede orodnika s kategorijo živosti ${ }^{+}$.

Pri nas se odklanja teza, da bi predvsem udeleženska vloga orodja imela tudi stavčnočlensko vlogo osebka, npr. Roka je premaknila žogo (< 'Janez je žogo premaknil z roko'). Celo v nevsakdanjih metonimičnih rabah osebka se namreč udeleženska vloga orodja (in tudi sredstva) umika v prislovno določilo orodja (ali sredstva), ki je najprimernejši nosilec domnevne vloge orodja ali sredstva, npr. Roka je premaknila žogo z mezincem. (Zgled je z vidika naravne rabe slovenščine prisiljen, kaže pa na normativne zmožnosti jezika.) Od tod tudi upravičena misel, da je pomen sredstva ali orodja skrit že v predložnem morfemu $z$, ta pa podeli vlogo orodniku (Orešnik 1992: 14, 24).

\subsection{T. i. sestavljeni udeleženci z vidika razmerij udeleženci : udeleženske} vloge : določila oz. obvezna dopolnila. Načeloma vsak udeleženec vsakič nastopa v eni udeleženski vlogi in je izražen z enim določilom. Posebnost so t. i. sestavljeni udeleženci, ki se pomensko in strukturnoskladenjsko lahko razdelijo v dve- ali več udeleženskih vlog in so posledično tudi izraženi z dvema določiloma ali več določili, npr. en udeleženec (kot delujoča celota) $\mathrm{v}$ dveh udeleženskih vlogah (s poudarjanjem posameznega telesnega dela) $\mathrm{v}$ Udarilo (mu) je na ledvice (dvovezljivo) nasproti Po navadi udari na ledvice (enovezljivo); ko je sestavljeni udeleženec delujoče bitje, npr. človek, so deli telesa lahko v vlogi obveznih (oz. obveznodružljivih) modifikatorskih dopolnil, npr. enovezljivo Dela /z rokami = obvezno dopolnilo/ (nasproti dvovezljivemu Boli ga roka ali trovezljivemu Udaril ga je $v$ ramo) ipd.

T. i. sestavljeni udeleženci so tako vezljivostna kot posledično tudi obveznodružljivostna posebnost, ker navadno zaradi njihove visoke stopnje vršilskosti en sestavni del udeleženca prevzame vodilno udeležensko vlogo vršilca/nosilca dejanja, drugi sestavni del udeleženca pa je v vlogi obveznodružljive okoliščine načina dejanja /ki je v nadaljnjih zgledih v poševnih oklepajih/, npr. Božal ga je /z očmi/ (kako? $\Rightarrow z$ očmi) - v teh primerih možna pretvorba Njegove oči so ga božale samo še potrjuje del telesa oz. organ kot delujoči del osebka.

V okviru obveznodružljivih dopolnil je treba poudariti, da glede na določeno specifiko pomenskosestavinskosti glagolov v povedku, na podlagi katere glagole razvrščamo v pomenske skupine, imajo bolj navadno obvezno izpridevniško prislovno dopolnilo glagoli ravnanja, stanja (nastopa stanja), poteka/procesa in premikanja s poudarjenimi pomenskimi sestavinami 'vedenja' ali 'razmerja';

${ }^{24}$ F. Daneš $(1987: 89>$ ) pravi, da se povedki z isto pomensko formulo povedja (SF - sémantická formule) razlikujejo glede na t. i. izbirne/selektivne pomenske težnje udeležencev (selekční sémantické tendence participantů). 
predvsem 'razmerje' napoveduje udeležensko vlogo 'razmerja dejanja', obe poudarjeni sestavini 'vedenja' in 'razmerja' s skupno nadsestavino 'odnosa' pa napovedujeta in vključujeta obvezen način, ki 'vedenje' in 'razmerje' lastnostno (kakovostno, kolikostno, vzročnostno) ali vrstno in primerjalno oz. oziralno (izudeležensko s sredstvom/orodjem, s primerjalnim/ozirnim (razmernim) udeležencem) opredeli. Najširše in najobširnejše možnosti uporabe obveznodružljivih dopolnil imajo splošnopomensko in oslabljenopomensko rabljeni glagolski pomeni.

\section{Nepropozicijski/zunanji udeleženec}

Nepropozicijski/zunanji udeleženec je hkrati tudi tvorec sporočila oz. tudi t. i. »modalni operater« (Kořenský 1984: 137) in zato se v zvezi z zunanjim udeležencem govori tudi o t. i. »vnešnoj modal'noj ramke« (nasproti »vnutrennoj sub' 'jektivnoj modal'nosti« (prim. Hrakovskij 1985: 15)), npr. Jutri bo morda dež. Tovrstno zunanjeudeležensko tvorčevo zaznavanje in ugotavljanje pojavnosti je izraženo v nepropozicijskih časovno-naklonskih določitvah, npr. Je bil hrup / Je bilo hrupno - Je bilo slišati hrup / Je škoda, da je tak hrup - to J. Kořenský (1984: 36) poimenuje kot »dicendialno semantiko«, ki omogoča ločevanje med bazičnimi pomenskimi lastnostmi in pragmatičnimi lastnostmi. Tako se samo še potrjuje misel Charlesa Ballyja, ki jo poudarja F. R. Mikuš (1945: 7), in sicer, da mora biti vsako jezikovno izražanje združevati logični, psihološki in jezikoslovni vidik obravnave, in to z vključevanjem neskladenjskopodstavnih sestavin in z upoštevanjem členitve po aktualnosti.

\section{0 obveznosti prislovnih in pridevniških dopolnil v povedi in besedilu}

Stopnja skladenjskopomenske obveznosti povedkovih prislovnih in pridevniških dopolnil je obratnosorazmerno odvisna tudi od stopnje polnopomenskosti uporabljenih glagolov v povedku. Splošnopomenske izpridevniške prislove tipa lepo, grdo, slabo, dobro Ju. D. Apresjan opredeljuje kot 'nemotivirano obvezno vsebinsko vezljivost', ki obenem izpostavi ali celo omogoči tudi vezljivostne posebnosti glagolov, npr. enovezljivost v smislu zamejitve vezljivosti samo na vršilskost, npr. dobro kuhati, lepo slikati. ${ }^{25}$

${ }^{25}$ Apresjanova 'nemotiviranost' je tu z vidika glagola mišljena kot pomenskoskladenjska neusmerjenost (nasproti glagolski pomenskoskladenjski usmerjenosti, ki jo enačimo z glagolsko vezljivostjo). Sicer pa pomensko- in strukturnoskladenjsko vlogo prislovn/ (o)zveznih dopolnil ruska skladenjska teorija označuje kot 'določnostno odvisnost' v nasprotju z 'udeležensko odvisnostjo', gl. Ju. D. Apresjan ('1995: 51, 130).

Češka skladenjska teorija, gl. Mluvnice češtiny - Skladba (1987: 18, 38, 192, 254), takšne primere označuje kot »syntagmata rozvitá«. Izpridevniška prislovna določila načina so opredeljena kot skladenjsko obvezna dopolnila (t. i. 'skladenjska relevanca', ki oblikuje 
4.1 Predvsem v okviru obveznodružljivih /ob/povedkovih prislovnih dopolnil so že velikokrat navajani in obravnavani primeri, ki še dodatno dokazujejo, da je smiselno obravnavati in opredeliti prislovna in pridevniška dopolnila tudi kot obvezne lastnostne dopolnilne sestavine povedka in s tem kot obvezne sestavine povedi in nadpovednih besedil, npr. Navadno hodi peš, Navadno hodi brez nogavic, Navadno hodi bos, Sava teče motna, kjer je vzajemna pomenskoskladenjska odvisnost povedkovega glagola in prislovnega oz. pridevniškega dopolnila več kot očitna, tako da sicer polnopomenski glagol zaradi svoje splošnopomenskosti ob konkretnem (celo specializiranem) polnopomenskem prislovnem ali pridevniškem pomenu propozicijsko oslabi, v zgornjih primerih glagola hoditi in teči ob prislovnih in pridevniških dopolnilih prehajajo v glagol biti. ${ }^{26}$ Tako zgoraj navedeni zgledi, tudi zaradi izpridevniškega prislova, izraža neaktualno oslabljeno glagolsko dejanje. Z vidika modifikacijskih dopolnil pa se v konkretnih zgledih potrjuje, da tudi splošnopomenskost prislovnega oz. pridevniškega dopolnila tipa lep/lepo, dober/dobro ni vedno in ob vsakem povedkovem glagolu pomenskoskladenjsko ustrezna oz. ustrezno povedna, npr. Lepo se (jim) je godilo - (Lepo) se jim godi / Godi se jim - (Lepo) se imajo / Imajo se - Dogajanje je bilo lepo - Na srečanju je bilo lepo - Srečanje je bilo lepo - *Lepo so se srečali, Dobro so se zabavali - Zabava je bila dobra ipd.

Izudeleženska obpovedkova prislovna dopolnila pa že delujejo (tudi) kot pretvorbna razmerja med vezljivostjo in obvezno družjivostjo - to so t. i. vrstni prislovi (SLP: 76-77) v vlogi prislovnih dopolnil, ki pretvorbno vključujejo tako delovalnike kot okoliščine, npr. Že večkrat so ga samo ambulantno zdravili, To obdeluje samo strojno, Dela honorarno, Politično deluje ipd.

4.2 Pridevniška obpovedkova dopolnila so v primerjavi s prislovnimi dopolnili malokrat obvezna. Pomenskoskladenjsko so pridevniška dopolnila lahko obvezna predvsem ob glagolih stanja ali procesa (ti vključujejo 'vedenje', 'razmerje z ravnanjem') in sicer, ko pomenskoskladenjsko oz. sporočilno prevladajo nad povedkovimi glagoli, katerih konkretni pomen zato pomenskoskladenjsko oslabi npr. Čaka prestrašen > Je prestrašen, On hodi poškodovan > Je poškodovan, Ravna/upravlja/govori nepodučen/nepripravljen > Je nepodučen/ nepripravljen, Živi razsipno > Je razsipen, Ustvarja/oblikuje navdahnjen/ pretresen $>$ Je navdahnjen/pretresen ipd. Nasproti pa se pridevnišk/(o)zvezn/a

'obrobni/stranski tip (okrajový typ) stavčnega vzorca') predvsem v izpeljanih stavčnih zgradbah v okviru sekundarne diateze - „adverbiální výrazy se stávají obligatorním komponentem derivované struktury«, v nasprotju s »syntagmatu valenční«.

${ }^{26}$ Pomisleke ob teh primerih je v oceni Nova slovenska skladnja J. Toporišiča (1984: 142-155) A. Vidovič Muha obrazložila: »/.../ Pomislek zbuja glagol hoditi, ki je v zvezi hoditi bos predstavljen kot polnopomenski - zveza naj bi se po znanem pravilu dala razstaviti v hoditi + biti bos, vendar pa se zdi, da taka razstavitev ni mogoča, npr. $P o$ leti (večkrat ipd.) hodim bos ne pomeni, da Poleti hodim + Sem bos, ampak enostavno Poleti sem bos (biti bos); glagola hoditi torej ne moremo brez pomislekov uvrstiti med polnopomenske« (150-151). 
dopolnila neobvezno pomenskoskladenjsko dodajajo glagolom dogodka/dejanja, npr. Vrnil se je bolan, Poškodoval ga je omamljen ipd.

5 Za konec velja poudariti, da glagolska vezljivost ujeta $\mathrm{v}$ stavkotvorna in besedilotvorna merila poudari skladenjske posebnosti posameznega jezika.

Glagol s svojo osrednjo skladenjskopomensko organizacijsko vlogo namreč poudarja zlasti tesno vzajemno oz. soodvisno povezanost med stavčnopovedno in glagolsko besednozvezno skladnjo; z obpovedkovimi oz. obglagolskimi prislovnimi dopolnili pa je omogočeno tudi sporočilno zgoščanje, ki ima medpropozicijsko vlogo in sega $\mathrm{v}$ nadpovedno/besedilno skladnjo.

\section{VIRI IN LITERATURA}

Jurij D. APRESJAN, Ju. D., ${ }^{2} 1995$ : Leksičeskaja semantika. Vostočnaja literatura RAN. 2. popravljena in dopolnjena izdaja. Moskva.

Anton BAJEC, 1959: Besedotvorje slovenskega jezika IV: Predlogi in predpone. Ljubljana: SAZU.

Danutta BUTTLER, 1976: Innowacje składniowe wspótczesnej polszczyzny (Walencja wyrazów). Warszawa: Państwowe wydawnictwo naukowe.

Ivanka ČERNELIČ KOZLEVČAR, 1979: O glagolih premikanja zlasti glede na glagol iti in stavčne vzorce. Jezik in slovstvo XXV. 45-47.

František DANEŠ idr., 1987: Větné vzorce v češtině. Praha: Academia.

Janez DULAR, 1982: Priglagolska vezava v slovenskem knjižnem jeziku (20. stoletja). Doktorska disertacija. Ljubljana. 1-259.

Charles John FILLMORE, 1968: The Case for Case. Universals in Linguistic Theory. Urednika E. Bach in R. T. Harms. USA.

Charles John FILLMORE, D. T. LANGENDOEN, 1971: Studies in Linguistic Semantics. New York.

Miroslav GREPL idr., 1987: Mluvnice češtiny (3 - Skladba). Praha: Academia.

Michel A. K. HALLIDAY, 1970: Language Structure and Language Function. New Horizons in Linguistics I. New York. 158-165.

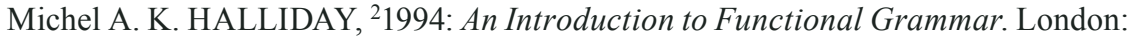
Edward Arnold.

Gerhard HELBIG, J. BUSCHA, 1984: Deutsche Grammatik. Ein Handbuch für den Ausländerunterricht. Leipzig: VEB Verlag Enzyklopädie. 137, 352-398, 535-564.

Vasilij S. HRAKOVSKIJ, V. S. idr., 1985: Tipologija konstrukcij s predikatnymi aktantami. Leningrad: Nauka.

Vatroslav KALENIĆ, 1970: Raba sklonov v slovenščini in srbohrvaščini. Slavistična revija XVIII/1-2. 107-128. 
František KOPEČNÝ, 1973: Základy české skladby. Praha: SPN.

Jan KOŘENSKÝ, 1984: Konstrukce gramatiky ze sémantické báze. Praha: Academia.

Olga KUNST GNAMUŠ, 1981: Pomenska sestava povedi. Ljubljana.

Ivana B. LEVONTINA, 1996: Celeobraznost' bez celi. Voprosy jazykoznanija XLV/1. 42-57.

Franciskus Radivoj MIKUŠ, 1945: Što je u stvari rečenica? Fragment iz teorije jezika i mišljenja. Ljubljana: U vlastitoj nakladi.

Janez OREŠNIK, 1992: Udeleženske vloge v slovenščini. Ljubljana: SAZU.

- -, 1994: Slovenski glagolski vid in univerzalna slovnica. Ljubljana: SAZU.

Jan ORLOVSKÝ, ${ }^{2} 1965$ : Slovenská syntax. Bratislava: Obzor.

Martina OROŽEN, 1975: Razvoj predložnih zvez v slovenskem jeziku. XI. seminar slovenskega jezika, literature in kulture. Ljubljana. 13-16.

Elena V. PADUČEVA, R. I. ROZINA, 1993: Semantičeskij klass glagolov polnogo ohvata: tolkovanie i leksiko-sintaksičeskie svojstva. Voprosy jazykoznanija XLII/6. $5-16$.

Emil PÁLEŠ, 1990: Sémantické roly slovenských slovies. Jazykovedný časopis XLI/1. Diskusie. 30-48.

Helen B. PARTEE, 1971: On the Requirement that Transformations preserve Meaning. Studies in Linguistic Semantics. New York. 1-21.

Emil PAULINY, 1943: Štruktúra slovenského slovesa (Štúdia lexikálno-syntaktická). Spisy Slovenskej akadémie vied a umeni 2. Bratislava.

Irena POGAČNIK OREL, 1993: Predložni sistem v razvoju slovenskega knjižnega jezika od 16. do 19. stoletja: disertacija. Ljubljana.

Ronald QUIRK idr., ${ }^{27} 1993$ : A University Grammar of English. Hong Kong.

Ronald QUIRK idr., ${ }^{20} 1994:$ A Comprehensive Grammar of the English Language. New York.

Jože TOPORIŠIČ, 1982: Nova slovenska skladnja (NSS). Ljubljana: DZS.

Ada VIDOVIČ MUHA, 1984: Nova slovenska skladnja J. Toporišiča. SR XXXII/2. $142-155$.

Ada VIDOVIČ MUHA, 1985: Primeri tvorbenih vzorcev glagola. XXI. seminar slovenskega jezika, literature in kulture. Ljubljana. 47-61.

Ada VIDOVIČ MUHA, 2000: Slovensko leksikalno pomenoslovje(SLP). Govorica slovarja. Ljubljana: Znanstveni inštitut Filozofske fakultete.

Ada VIDOVIČ MUHA, 2009: Skladenjska interpretacija glagolskih predponskih obrazil - vprašanje propozicije. Slavistična revija 57/2. 251-261. 


\section{SYNTACTICAL PECULIARITIES OF SLOVENIAN IN VERB, VALENCY AND SENTENCE PATTERN RELATIONS}

This paper discusses a co-dependant relationship between verbal valency and clauseforming capabilities in one-clause sentences. Verbs with semantic properties represent a peculiarity of the Slovenian language from the standpoint of valency and clausal capabilities, allowing the agent and the patient to function on the same (or at least similar) level. The semantic aspect of verbs that allow for the merging of the agent and patient roles contains the component of 'motion', which because of inherent 'self-motion' or 'self-action', can eliminate the need for the reflexive pronoun se. In this way the following relations are established: Veter giblje/premika veje > Veje se gibljejo/premikajo (the colloquial version is: *Veje gibljejo). Words such as bivati (to exist) and čustvovati (to emote) contain an element of 'procession', which is nothing more than simplified 'motion and change'. Similar sentence-clausal relations can be established in verbs containing the reflexive pronoun se, such as Amortizirali so stroj : Stroj se je amortiziral, Angažirali so umetnika: Umetnik se je angažiral, Bočili so pločevino : Pločevina se je bočila, etc. A broad enough semantic base of a given verb enables double valency (prepositional and non-prepositional), providing a choice between different meanings of the verb. In this case, we talk about verbs or verbal meanings that allow for at least three potential/ possible participant roles with three participants, of which one may be left unexpressed because it functions as a component part of the verb or the expressed (complex) participant, e.g. izčistiti 'odstraniti/očistiti' madež z obleke : izčistiti 'odstraniti' madež : izčistiti 'očistiti' obleko, etc. The clause-forming non-participant and hence non-proper valency of verbs in weather-related sentences besides clause-forming one-part expressions, such as Dežuje, Lije, Piha, etc., enables such seeming two-part clause-forming variations as Dež je / Dež grelpada, Dež lije, Veter piha, etc.

Adverbial complements derived from participant roles function (also) as transformational relations between valency and obligatory collocability. These are the so-called adverbs of type in the role of adverbial complements, which from the transformational perspective include both agents and circumstances, e.g. Že večkrat so ga samo ambulantno zdravili, To obdeluje samo strojno, Dela honorarno, Politično deluje, etc. The non-prepositional temporal/mood formulations such as Je bil hrup / Je bilo hrupno - Je bilo slišati hrup I Je škoda, da je tak hrup, etc., express the notion that at least some kind of an external participant or agent is present. 